\title{
The effect of sectoral gender employment on total number of Small and Medium Enterprises (SME's) in Nigeria.
}

\author{
Chukwu Agnes U. ${ }^{1}$ Oko-Isu Anthony ${ }^{2}$ \\ 1. Department of Human Resources Management, College of Management sciences, Michael Okpara University \\ of Agriculture, Umudike, Abia State, Nigeria. \\ 2. Department of Agribusiness and Management, College of Management sciences, Michael Okpara University \\ of Agriculture, Umudike, Abia State, Nigeria.
}

\begin{abstract}
Gender equality is a fundamental human right. At the same time it also makes good economic sense because it means using the country's human capital more efficiently. It can have profound benefits not just for women themselves but also for families, communities and national economies. As such, this study delved into the effect of sectoral gender employment on the total number of SME's in Nigeria. The study employed secondary data from SMEDAN on the sectoral employments by SME's and also the total number of SME's in Nigeria by sector. Data were analyzed using multiple regression analysis and the Pearson's correlation coefficient. The multiple regression analysis result showed that female employment at commencement was significant at $5 \%$ and positively contributed to total number of SME's while; female employment later was also significant at 5\% but negatively contributed to the total number of SME's in Nigeria. On the basis of the results, the study suggested that more women should be employed at the startup of new SME's and subsequently after infancy stage more males should be then be introduced as a panacea to the decrease in SME's and also survival of already existing ones in Nigeria.
\end{abstract}

Keywords: Sectoral gender employment, Small and Medium Enterprises (SME's), Nigeria.

\section{Introduction}

Research into small and medium sized enterprises (SMEs) has grown during the last decade. A huge majority of firms worldwide are SMEs, and they play a significant role in the economy (Islam et al, 2011). Consequently, the performance of the SME sector is closely associated with the performance of the nation. However, researches on the effect of gender employment by SME owners is rare as researchers have not keenly observed the significance of gender employment on the number of SME startups and its attendant contribution to national economic development of developing countries such as Nigeria where rate of unemployment is high. According to Aspiring minds (2013) small firms, startups and medium sized enterprises often find recruiting quality talent a challenge. Typically not a large brand, limited marketing resources and restricted reach make it hard to locate and acquire high quality talent. On the other hand, the need for quality and trained talent is all the more important due to the lack of training and mentoring infrastructure available in larger setups. The smaller scale makes it harder for SMEs to either develop or employ statistically accurate evaluation tools or maintain relationships with qualified candidates and sourcing partners. This has lead to employment bias by SME owners. International Labour Organization (ILO) (2003c) opined that despite some progress made over the last few decades in increasing women's labour force participation and narrowing gender gaps in wages, gender equality in the world of work still remains an elusive goal. While millions of women have become successful entrepreneurs, women are still grossly underrepresented in the world's board rooms. In particular, in the developing world, women continue to form a large majority of the world's working poor, earn less income, and are more often affected by long-term unemployment than men. This is due to women's socio-economic disadvantages caused by gender-based discrimination and their double roles of being a worker and a care taker for the society. Women often have less access to productive resources, education, and skills development and labour market opportunities than men in many societies. Largely, this is because of persistent social norms ascribing gender roles, which are often, slow to change. Furthermore, women continue to undertake most of unpaid care work, which has become an increasing challenge in their efforts to engage in productive work, both in subsistence agriculture and market economy, especially in countries which are negatively affected by environmental change and HIV and AIDS.

Nigeria has been described as a nation of traders with a very weak and stagnant domestic private sector economy consisting of a few huge multinationals and a large segment of essentially informal micro, small, and medium enterprises (NPC, 2004). Nationally, about 21 per cent of workers are employed by a large or small private enterprise, ranging from a low of 10.8 per cent in the North East region to a high of 29 per cent in the South West region (ILO, 2010). The majority of workers are employed by a private person or household (over 69 per cent), rising to over 80 per cent in the North East. In 2005, over 75 per cent of households reported being 
involved in enterprise activity, with an average of 2.3 persons per enterprise (Nigerian Bureau of Statistics (NBS), 2009). Presumably, these are informal workers, confirming that the informal economy is the major source of livelihood for Nigerians. In fact, the share of informal economy employment in total employment is one of the highest in sub-Saharan Africa (World Bank, 2009).

Nigeria's socio-economic conditions in the last two decades have been characterized by unemployment crises and mass poverty. The federal government's concern for the menacing problem of mass unemployment in the mid-1980s spurred the setting up of the National Directorate of Employment (NDE) in 1986, the Work for Yourself Programme in 1987 and Small and medium Scale Enterprises Development Agency of Nigeria (SMEDAN) in 2003 to create jobs by providing training and financial support to encourage self-employment activity. Although the NDE achieved a lot in promoting employment, creating wealth, and alleviating poverty, Nigeria's official unemployment rate in 2009 was 19.7 per cent, up from 11.9 per cent in 2005 (NBS, 2010). However, the rate of unemployment among women and, particularly, young people is much higher. In addition, over 23 million of the 40 million unemployed youth in Nigeria are deemed to be unemployable due to poor quality education and lack of job skills. Given that youth between the ages of 15 and 30 represent 47 per cent of the nation's productive population, this a serious situation which is being addressed as an issue in the government's Vision 20:2020 Implementation Plan (Federal Republic of Nigeria, 2010).

The Small and Medium Enterprises are globally acknowledged as the oil required to lubricating the engine of socio-economic transformation of any nation. The SME sector is strategically positioned to absorb up to $80 \%$ of jobs, improve per capita income, increase value addition to raw materials supply, improve export earnings and step up capacity utilisation in key industries. The sector is structured across other key sectors, including Agriculture, Mining and Quarrying, Building and Construction, Manufacturing, Solid Minerals, etc, and thus has strong linkages with the entire range of economic activities in the country.

It is therefore on the above premise that this Survey was conceived as a concerted response to the challenges of enhancing the performance and thereby increasing the number of entrepreneurs venturing into SME's in other to strategically reduce the rate of gender inequalities on employment, place Nigeria among the committee of Nations adhering to the ILO standards and charter and also reposition the SME sector with its attendant contribution to Nigeria's economy.

\section{Materials And Method}

This study employed secondary data which were sourced from latest 2012 survey report on SME's by SMEDAN. Data collected were analyzed using the multiple regression analysis and the Pearson's correlation coefficient. The multiple regressions was used to analyze the effect of gender employment on the total number of SME start ups in Nigeria while, the Pearson's correlation coefficient was used to examine the degree of relationship existing between SME startups and sectoral gender employments.

The multiple regression model is specified thus:

$\mathrm{Y}=\mathrm{X} 1+\mathrm{X} 2+\mathrm{X3}+\mathrm{X} 4+\mathrm{X} 5+\mathrm{e}$

Where,

$\mathrm{Y}=$ Number of SME startups based on sectors

$\mathrm{X} 1=$ Female employment at SME commencement based on sectors

$\mathrm{X} 2$ = Male employment at SME commencement based on sectors

$\mathrm{X} 3=$ Total latest number of employments of both male and female based on sectors

$\mathrm{X} 4=$ Male employments latest based on sectors

$\mathrm{X} 5=$ Female employments latest based on sectors

$\mathrm{e}=$ error term

The Pearson's correlation coefficient on the other hand is specified thus:

$\mathrm{r}=\underline{\mathrm{n} \Sigma \mathrm{xy}-\Sigma \mathrm{x} \Sigma \mathrm{y}}$

$\frac{\sqrt{n} \Sigma x^{2}-(\Sigma x)^{2}}{\sqrt{n} \Sigma y^{2}-(\Sigma y)^{2}}$

Where $\mathrm{r}=$ correlation coefficient

$\mathrm{Y}=$ Number of SME startups based on sectors

$\mathrm{X}$ 's $=$ all the aforementioned independent variables of the regression

$\mathrm{n}=$ observation size

\section{Results and Discussion}

In analyzing the effect of sectoral gender employment on the total number of SME startups in Nigeria, the multiple regression analysis was employed and the result presented in table 1 . The four functional forms of the multiple regression analysis was employed and from the results as shown in table 1 the exponential functional form was chosen as the lead equation for the result interpretation based on its highest number of significant variables and the a priori expectations of the study. 
From the results it is observed that female employment at SME commencement with the total later employment were significant at 5\% and $10 \%$ respectively and positive contributed also to total number of SME startups while, female later employment was significant at 5\% but negatively contributed to total number of SME startups in Nigeria.

By implication, the positive significant contribution of female employment at commencement of SME's means that females stand out as a valuable variable in determining SME's startup, performance and/or survival at both the startup and/or infant stage. However, the negative but significant contribution of the later female employment implies that female employees are no more valuable variables when the SME's are off the infant stage.

The implication of this result is that women who are good caretakers and prudent managers according to ILO reports (2010) are the most valuable in SME's employment quarter during its startups and infant stage but once it is off the stage of infancy and much pressure, demand and stress are placed on the females, their contributions and effect tend to affect the SME startups maybe through observation by onlookers who are studying the SME's to see if they too can venture into anyone.

The $\mathrm{R}^{2}$ (coefficient of multiple determination) of 0.941 indicates that $94.1 \%$ of the variation in the dependent variable (Y) were accounted for by the independent variables. The F-statistic figure of 42.565 which was significant at $1 \%$ indicates that the model was adequate.

Table 1: Regression result of the effect of sectoral gender employment on the total number of SME startups in Nigeria.

\begin{tabular}{|c|c|c|c|c|}
\hline parameter & Linear & +Exponential & Double log & Semi-log \\
\hline Constant & $\begin{array}{l}6.864 \\
(0.092)\end{array}$ & $\begin{array}{l}5.494 \\
(29.392)^{* * *}\end{array}$ & $\begin{array}{l}-0.145 \\
(-1.973)^{*}\end{array}$ & $\begin{array}{l}9865.442 \\
(-5.059)^{* *}\end{array}$ \\
\hline $\begin{array}{l}\text { Male employment at } \\
\text { commencement }\end{array}$ & $\begin{array}{l}-2.439 \\
(-1.780)\end{array}$ & $\begin{array}{l}0.009 \\
(2.764)^{* *}\end{array}$ & $\begin{array}{l}-0.144 \\
(-0.823)\end{array}$ & $\begin{array}{l}-7574.257 \\
(-1.636)\end{array}$ \\
\hline $\begin{array}{l}\text { Female employment at } \\
\text { commencement }\end{array}$ & $\begin{array}{l}1.773 \\
(1.093)\end{array}$ & $\begin{array}{l}0.000 \\
(-0.047)\end{array}$ & $\begin{array}{l}0.293 \\
(0.514)\end{array}$ & $\begin{array}{l}2065.412 \\
(0.136)\end{array}$ \\
\hline Total later employment & $\begin{array}{l}0.643 \\
(18.739)^{* * *}\end{array}$ & $\begin{array}{l}0.001 \\
(2.008)^{*}\end{array}$ & $\begin{array}{l}0.995 \\
(35.703)^{* * *}\end{array}$ & $\begin{array}{l}1429.452 \\
(4.949)^{* * *}\end{array}$ \\
\hline Male employment later & $\begin{array}{l}-0.699 \\
(-0.429)\end{array}$ & $\begin{array}{l}0.001 \\
(0.132)\end{array}$ & $\begin{array}{l}0.809 \\
(1.462)\end{array}$ & $\begin{array}{l}1962.207 \\
(0.134)\end{array}$ \\
\hline Female employment later & $\begin{array}{l}2.183 \\
(1.588)\end{array}$ & $\begin{array}{l}-0.009 \\
(-2.459)^{* *}\end{array}$ & $\begin{array}{l}0.058 \\
(0.310)\end{array}$ & $\begin{array}{l}5047.008 \\
(1.010)\end{array}$ \\
\hline F-statistics & 612.834 & 42.565 & 3071.122 & 10.869 \\
\hline $\mathrm{R}^{-2}$ & 0.996 & 0.919 & 0.999 & 0.782 \\
\hline $\mathrm{R}^{2}$ & 0.997 & 0.941 & 0.03325 & 0.861 \\
\hline
\end{tabular}

, and indicates significance at 1, 5 and 10-percent levels respectively.

Source: computed from SMEDAN Report data, 2012.

Table 2: Correlate examination of the degree of relationship between total SME startups and sectoral employments of SME's in Nigeria.

\begin{tabular}{|c|c|c|c|c|c|c|}
\hline & $\begin{array}{l}\text { Total SME by } \\
\text { sector }\end{array}$ & $\begin{array}{l}\text { Female } \\
\text { employment at } \\
\text { commencement }\end{array}$ & $\begin{array}{l}\text { Male employment at } \\
\text { commencement }\end{array}$ & $\begin{array}{l}\text { Total } \\
\text { employment } \\
\text { later }\end{array}$ & $\begin{array}{l}\text { Male } \\
\text { employment } \\
\text { later }\end{array}$ & $\begin{array}{l}\text { Female } \\
\text { employme } \\
\text { nt later }\end{array}$ \\
\hline \multicolumn{7}{|l|}{ Total SME by sector } \\
\hline & 1 & & & & & \\
\hline \multicolumn{7}{|l|}{$\begin{array}{l}\text { Female employment } \\
\text { at commencement }\end{array}$} \\
\hline & $0.938^{* *}$ & 1 & & & & \\
\hline \multicolumn{7}{|l|}{$\begin{array}{l}\text { Male employment at } \\
\text { commencement }\end{array}$} \\
\hline & $0.997^{* *}$ & $0.954^{* *}$ & 1 & & & \\
\hline $\begin{array}{l}\text { Total employment } \\
\text { later }\end{array}$ & $0.986^{* *}$ & $0.981^{* *}$ & $0.994^{* *}$ & 1 & & \\
\hline Male employment & & & & & & \\
\hline later & $0.997^{* *}$ & $0.955^{* *}$ & $1.000^{* *}$ & $0.994^{* *}$ & 1 & \\
\hline $\begin{array}{l}\text { Female employment } \\
\text { later }\end{array}$ & $0.950^{* *}$ & $0.999^{* *}$ & $0.965^{* *}$ & $0.988^{* *}$ & $0.965^{* *}$ & 1 \\
\hline
\end{tabular}

indicates correlation is significant at the 0.01 level (2-tailed)

Source: computed from SMEDAN Report data, 2012.

Table 2 shows the correlate examination of the degree of relationship existing between the total number of SME startups, female employment at commencement, male employment at commencement, total employment later, male employment later and female employment later. 
From the result as shown by table 2, it can be depicted that all of the variables were highly correlated and thus highly related to SME startups and also to each other at the highest correlation significant levels of 0.01 (2tailed).

The result implication of the positive significant relationships is that both male and female employees of SME's are all highly related to the number of SME startups of the various sectors in Nigeria.

\section{Conclusions}

Conclusively, having analyzed the effect of sectoral gender employments on the total number of SME's in Nigeria using the multiple regression model and the Pearson's correlation coefficient, it could be inferred that more women should be employed at the startup of new SME's and subsequently after infancy stage more males should be then be introduced. This may serve as a panacea to the decrease in SME's and also survival of already existing ones in Nigeria.

\section{Acknowlegement:}

The authors are thankful to the contributions of Mr. G.O. Chukwu and family towards the successful completion of this research.

\section{References}

[1]. Anyanwu, S.O. 2009. 'Assessing the Business Environment for Women Entrepreneurship Development in Nigeria', prepared for the International Labour Organisation, Abuja, Nigeria: University of Abuja.

[2]. Federal Ministry of Justice. 2008. 'Nigeria's 3rd Periodic Country Report: 2005-2008 on the Implementation of the African Charter on Human and People's Rights in Nigeria', September, Abuja, Nigeria: Federal Republic of Nigeria.

[3]. Federal Republic of Nigeria. 2010. Nigeria Vision 20:2020, The First National Implementation Plan (2010-2013), May, Abuja, Nigeria: Federal Republic of Nigeria.

[4]. ILO, 2011. Assessment of the environment for the development of women's entrepreneurship in Cameroon, Mali, Nigeria, Rwanda and Senegal / Lois Stevenson, Annette St-Onge ; International Labour Office, Employment Sector, Small Enterprise Programme, Job Creation and Enterprise Development Department. - Geneva: ILO, 20111 v. (Employment report ; No.15) ISBN: 9789221255246; 9789221255253 (web pdf) International Labour Office; Job Creation and Enterprise Development Dept women workers / entrepreneurship / small enterprise / Cameroon / Mali / Nigeria / Rwanda / Senegal 14.04.2

[5]. - 2005. Assessing the Enabling Environment for Women in Growth Enterprises: An AfDB/ILO Integrated Framework Assessment Guide, Geneva, Switzerland: International Labour Office and Tunis, Tunisia: African Development Bank.

[6]. - 2003c. Jobs, Gender and Small Enterprises in Africa, Tanzanian Women Entrepreneurs: Going for Growth, ILO Regional Office and Ministry of Industry \& Trade, SME Section, Geneva, Switzerland: International Labour Organization.

[7]. Islam, A.M, Khan A.M, Obaidullah M.Z.A and Alam S.M, (2011). Effect of entrepreneurship and firm characteristics on the business success of Small and Medium Scale Enterprises (SME's) in Bangladesh. International journal of business and management. Vol.6, No3. www.ccsenet.org/ijbm.

[8]. NBS (National Bureau of Statistics). 2010. 'Statistical News, Labour Force Statistics'.Available at: http://www.nigerianstat.gov.ng/ext/latest release/LabourForcestat.pdf [04 Oct. 2011]

[9]. - 2009a. Annual Abstract of Statistics 2009, Abuja, Nigeria: Federal Republic of Nigeria.

[10]. - 2009b. Women and Men in Nigeria, Volume One, 2001-2007, Abuja, Nigeria: Federal Republic of Nigeria.

[11]. NPC (National Planning Commission). 2004. 'Nigeria: National Economic Empowerment and Development Strategy (NEEDS)', NEEDS Secretariat, March, Abuja, Nigeria: Federal Republic of Nigeria.

[12]. Olutunla G.T. 2008. 'Policy Framework and Strategy for Entrepreneurship Development of Nigerian Women', paper presented at the 3-day International workshop on "Promoting Entrepreneurship Education Amongst Nigerian Women: Issues and Approaches", Abuja, Nigeria.

[13]. SMEDAN (Small and Medium Enterprises Development Agency of Nigeria). 2012. 'National survey report 2010 of Micro, Small and Medium enterprises (MSME's) in Nigeria.

[14]. Collaborative report of SMEDAN and NBS may, 2012, Abuja, Nigeria: SMEDAN.

[15]. World Bank, 2009. Nigeria Employment and Growth Study, Financial and Private Sector Development Department, Country Department 12, Africa Region, Washington, DC, USA: World Bank. 